\section{Parent Identification of Eight Apple Cultivars by S-RNase Analysis and Simple Sequence Repeat Markers}

\author{
Kentaro Kitahara and Shogo Matsumoto ${ }^{1}$ \\ Department of Biology, Faculty of Education, Gifu University, Gifu 501- \\ 1193, Japan
}

Toshiya Yamamoto and Junichi Soejima

National Institute of Fruit Tree Science, Tsukuba, Ibaraki 305-8605, Japan

Tetsuya Kimura

National Center for Seeds and Seedlings, Tsukuba, Ibaraki 305-0852, Japan

Hiromitsu Komatsu

Nagano Fruit Tree Experiment Station, Nagano 382-0072, Japan

\section{Kazuyuki Abe}

Department of Apple Research, National Institute of Fruit Tree Science, Morioka 020-0123, Japan

Additional index words. Malus $\times$ domestica, microsatellites, parentage analysis, simple sequence repeat, $S$-RNase allele

Abstract. As the parents of the some of the apple cultivars were unknown and others were uncertain, we investigated the parent-offspring relationships of eight apple cultivars by S-RNase analysis and SSR markers. The paternal parent of 'Hida' was identified as 'Golden Delicious', not the previously mentioned 'Orin'. It was indicated that 'Ryoka No Kisetsu' and 'Korin' showing identical SSR genotype are likely sports of 'Fuji'. 'Fuji', rather than 'Toko', seemed to be a maternal parent of 'Kotoku', but was not a paternal parent of 'Orei', 'Starking Delicious', 'Nero 26', 'Empire', or 'Aori 3'. Previously mentioned 'Mutsu', 'Indo', and 'Shin Indo' were excluded as paternal parents of 'Hokuto'. 'Tsugaru' and 'Jonathan' and were identified as the respective paternal parents of three cultivars described as having unknown paternal parents, i.e., 'Aika No Kaori', 'Yoko', and 'Tsugaru'.

Apples (Malus $\times$ domestica Borkh.) are produced commercially throughout most temperate-climate zones. In Japan, modern commercial apple production averages 1 million tons each year. 'Fuji', grown in $50 \%$ of the total cultivated area, is the leading cultivar, followed by 'Tsugaru' (14\%) and 'Orin' (10\%) (Soejima et al., 2000).

Apples exhibit gametophytic self-incompatibility (GSI), causing self pollen tube growth to be arrested in the style. GSI enforces outbreeding and results in heterozygosity. The $S$-RNase gene located within the $S$-locus encodes ribonucleases (Franklin-Tong and Franklin, 2003; McClure et al., 1989). From the nucleotide sequences of the S-RNases, the

Received for publication 26 May 2004. Accepted for publication $30 \mathrm{Aug}$. 2004. We wish to thank T. Kobayashi and Y. Miyamoto for supplying the plant samples and offering useful suggestions. We are also indebted to T. Fukazawa-Akada for her useful suggestions and R. Horiguchi for her technical assistance. This research was supported by a Grant-in-Aid for Scientific Research from the Ministry of Education, Culture, Sports, Science and Technology of Japan (Nos. 14360019 and 15208004).

${ }^{1}$ Correspondence address: Shogo Matsumoto, Department of Biology, Faculty of Education, Gifu University, Yanagido, Gifu 501-1193, Japan; e-mail shmatsum@cc.gifu-u.ac.jp.
PCR-based S-RNase allele genotype analysis method was developed (Broothaerts, 2003; Kitahara and Matsumoto, 2002a; Matsumoto and Kitahara, 2000). To date, we investigated the $S$-RNase content of more than 300 apple cultivars, lineages and species, and found that the pedigrees of some cultivars were uncertain due to discrepancies in the inheritance of $S$ genes (Matsumoto et al., 2003a, 2003b).

Simple sequence repeats (SSRs, also called microsatellites) have become the accepted markers of plant species, and SSR markers have been used for parentage analyses in grapes (Bowers and Meredith, 1997; Bowers et al., 1999; Sefc et al., 1997), peaches (Testolin et al., 2000; Yamamoto et al., 2003), and pears (Kimura et al., 2003).

Determining accurate parent-offspring relationships is important for the development of efficient apple-breeding programs. We selected 'Tsugaru', one of the major cultivars in Japan, and seven important cultivars having 'Fuji' or 'Golden Delicious' as a maternal parent, and then investigated their parentages using 19 SSR markers.

\section{Materials and Methods}

Plant material. T. Kobayashi and Y. Miyamoto supplied 'Hida B6' and 'Hida B7'.
Other Malus plants used in this study were from collections at the Apple Research Center of the National Institute of Fruit Tree Science, Japan, or the Nagano Fruit Tree Experiment Station, Japan. Young leaves were collected and stored at $-80^{\circ} \mathrm{C}$ until use.

$S$-RNase allele specific PCR-digestion analysis. Total DNA from the leaves of individual plants was isolated as described by Thomas et al. (1993). The primers and conditions used for the $S$-RNase allele-specific PCR amplification and digestion were essentially those described by Broothaerts (2003) (S2-, S3-, S4-, S7-, S9-, and S16-RNase allele), Kitahara et al. (2000) ( $S 24$-RNase allele), Kitahara and Matsumoto (2002b) (S10-RNase allele), Kitahara and Matsumoto (2002a) (S25-RNase allele), Matsumoto et al. (1999a) (S5- and S7-RNase allele), Matsumoto et al. (1999b) (S1- and S20-RNase allele), and Matsumoto and Kitahara (2000) (S28-RNase allele).

SSR amplification and parentage analysis. We used the following 19 SSR markers: CH01c06, CH01d08, CH01d09, CH01f03b, $\mathrm{CH} 01 \mathrm{f07a}, \mathrm{CH} 01 \mathrm{~g} 05, \mathrm{CH} 02 \mathrm{~b} 07, \mathrm{CH} 02 \mathrm{c02b}$, $\mathrm{CH} 02 \mathrm{c} 09, \mathrm{CH} 02 \mathrm{~d} 08, \mathrm{CH} 02 \mathrm{~g} 04, \mathrm{CH} 03 \mathrm{a} 04$, CH03a09, CH03d07, CH03d12, CH03e03, $\mathrm{CH} 05 \mathrm{a} 04, \mathrm{CH} 05 \mathrm{c0}$, and $\mathrm{CH} 05 \mathrm{~g} 08$ (Liebhard et al., 2002). PCR was conducted in a $20-\mu \mathrm{L}$ mixture comprised of $10 \mathrm{~mm}$ Tris- $\mathrm{HCl}(\mathrm{pH} 8.3)$, $50 \mathrm{~mm} \mathrm{KCl}, 1.5 \mathrm{mM} \mathrm{MgCl}_{2}, 0.01 \%$ gelatin, 200 $\mu \mathrm{M}$ deoxynucleotides, $0.5 \mu \mathrm{M}$ of each of three forward primers labeled with a fluorescent chemical (FAM, VIC, or NED) in addition to an unlabelled reverse primer, $10 \mathrm{ng}$ of genomic DNA, and a 1 unit of Taq polymerase. We did not combine the three primer pairs in the same PCR reaction. The analysis was programmed in a thermal cycler (GeneAmp 2700 apparatus; PE Applied Biosystems) and conducted under the following conditions: $5 \mathrm{~min}$ preheating at $94{ }^{\circ} \mathrm{C}, 1 \mathrm{~min}$ at $94{ }^{\circ} \mathrm{C}, 1 \mathrm{~min}$ at $55^{\circ} \mathrm{C}$, and $2 \mathrm{~min}$ at $72{ }^{\circ} \mathrm{C}$ for 35 cycles, followed by an extension for $7 \mathrm{~min}$ at $72{ }^{\circ} \mathrm{C}$. The PCR products were basically diluted about 10 to 20 times with distilled water, then separated and detected using a PRISM 310 DNA sequencer (PE Applied Biosystems). The size of the amplified bands was calculated based on an internal standard DNA (GeneScan 400HD Rox, PE Applied Biosystems) with GeneScan software (PE Applied Biosystems).

\section{Results and Discussion}

Parentage analysis of 'Hida' ' Hida' (sowed in 1972, selected in 1978, registered in 1985) was produced from an orchard of 'Fuji' ('Ralls Janet' was crossed with 'Delicious' in 1939, selected in 1958, registered in 1962) and 'Orin' ('Golden Delicious' was crossed with 'Indo', named in 1952). However, the $S$-RNase content of 'Hida' $\left(S_{3} S_{9}\right)$ did not match any of the expected $S$-RNase contents from its supposed parents 'Fuji' $\left(S_{1} S_{9}\right)$ and 'Orin' $\left(S_{2} S_{7}\right)$ (Matsumoto et al., 2003a). We confirmed the $S$-RNase content of 'Hida' as $S_{3} S_{9}$ using the plants 'Hida B6' and 'Hida B7' from the Hida region of Japan (data not shown). From the $S$-RNase content, $S_{9}$ seemed to be inherited from its maternal parent 'Fuji' $\left(S_{l} S_{9}\right)$, and $S_{3}$ 
not from its paternal parent 'Orin' $\left(S_{2} S_{7}\right)$, but from an unknown paternal parent having an $S_{3}$. 'Golden Delicious' (introduced into Japan in 1923) and 'Orei' ('Golden Delicious' was crossed with 'Delicious' in 1932, selected in 1947, registered in 1951) had been planted with 'Orin' within or nearby the orchard that produced 'Hida'. 'Golden Delicious' $\left(S_{2} S_{3}\right)$, not 'Orei' $\left(S_{2} S_{28}\right)$ seemed to be the paternal parent of 'Hida' based on their $S$-RNase contents. We investigated 19 SSR loci to confirm the paternal parent of 'Hida'. All 38 alleles in 'Hida' had been inherited from 'Fuji' and 'Golden Delicious' without discrepancy (Table 1), confirming that 'Hida' is a hybrid of those two cultivars (Table 2 ).

Parentage analysis of 'Ryoka No Kisetsu' and 'Hokuto'. A chance seedling, 'Ryoka No Kisetsu', was discovered at 1981 from an orchard of 'Fuji' and 'Starking Delicious' (introduced into Japan in 1929), and has been considered to be a hybrid of 'Starking Delicious' $\left(S_{9} S_{28}\right) \times$ 'Fuji' $\left(S_{l} S_{q}\right)$ or a sport of 'Fuji' $\left(S_{l} S_{g}\right)$ based on its $S$-RNase content $S_{l} S_{g}$ (Matsumoto et al., 2003a). All 38 alleles from the 19SSR loci in 'Ryoka No Kisetsu' matched completely those in 'Fuji' (Table 1), strongly suggesting that 'Ryoka No Kisetsu' was a sport of 'Fuji' (Table 2). However, we could not deny the possibility of a 'Starking Delicious' $\times$ 'Fuji' parentage since all 38 alleles in 'Ryoka No Kisetsu' could have been inherited from those two cultivars (Table 1).

Although the maternal and paternal parents of 'Hokuto' (selected in 1980, registered in 1983) were thought to be 'Fuji' and 'Mutsu' ('Golden Delicious' was crossed with 'Indo' in 1930, selected in 1939, registered in 1949), respectively, Sakurai et al. (1997) pointed out that 'Mutsu' $\left(S_{2} S_{3} S_{20}\right)$ was not the true paternal parent of 'Hokuto' $\left(S_{l} S_{f} S_{q}\right)$ based on their $S$-RNase contents, whereas 'Indo' (sowed in 1875 , the first cultivar produced in Japan) $\left(S_{7} S_{20}\right)$ seemed to be its true paternal parent based on its $S$-RNase content and genetic markers relating to Alternaria blotch disease, etc. (Fukazawa-Akada, personal communication). In the case of triploid, such as 'Hokuto' and 'Mutsu', $2 \mathrm{n}$ and $\mathrm{n}$ gamete are contributed from the maternal and paternal parent, respectively. The allele of one locus $(222,224$, and $228 \mathrm{bp}$ at $\mathrm{CH} 02 \mathrm{~d} 08$ ) in 'Mutsu' was not inherited by 'Hokuto' (Table 1). Assuming that 'Fuji' is the maternal parent of 'Hokuto', the alleles of one locus in 'Mutsu' (146 bp at CH01g05) and six loci in 'Indo' (200 bp at CH03e03, 139 bp at $\mathrm{CH} 03 \mathrm{a} 09,218$ bp at $\mathrm{CH} 03 \mathrm{~d} 07,188$ bp at $\mathrm{CH} 01 \mathrm{c} 06,186 \mathrm{bp}$ at $\mathrm{CH} 05 \mathrm{c} 04$ and 192 bp at $\mathrm{CH} 02 \mathrm{~g} 04$ ) were not inherited by 'Hokuto' (Table 1). Based on those results, both 'Mutsu' and 'Indo' would have to be excluded as paternal parents of 'Hokuto'. We examined another candidate for 'Hokuto' paternal parentage 'Shin Indo' ('Indo' was crossed with 'Golden Delicious' in 1930, selected in 1947, named in 1948), but one locus in 'Shin Indo' (206 bp and 218 bp at $\mathrm{CH} 03 \mathrm{~d} 07$ ) was not inherited by 'Hokuto' (Table 1). Moreover, neither 186 bp at $\mathrm{CH} 05 \mathrm{c} 04$ nor 192 bp at $\mathrm{CH} 02 \mathrm{~g} 04$ were inherited by it on the basis of its maternal parent 'Fuji' (Table 1), indicating that 'Shin Indo' must also be excluded as the paternal parent of 'Hokuto' (Table 2). One of the clones that vanished during the breeding program and thus was not registered as a new cultivar might also have been used as a paternal parent of 'Hokuto'

Parentage analysis of 'Aika No Kaori', 'Korin', 'Kotoku', 'Tsugaru', and 'Yoko'. The paternal parents of 'Aika No Kaori' (sowed in 1972, registered in 2001), 'Korin' (breeding process are largely unknown), 'Kotoku' (sowed in 1971, selected in 1979, registered in 1985), 'Tsugaru' (crossed in 1930, selected in 1943, registered in 1975) and 'Yoko' (sowed in 1962, selected in 1969 , registered in 1981) are unknown. 'Yoko' $\left(S_{3} S_{9}\right)$ or 'Tsugaru' $\left(S_{3} S_{7}\right)$ is likely to have been used as a paternal parent of 'Aika No Kaori' $\left(S_{3} S_{q}\right)$ based on its $S$-RNase content analysis, and fruit and branch characteristics (Matsumoto et al., 2003a; Komatsu, unpublished results). Within the 19 SSR loci, four loci in 'Yoko' (135 bp and $143 \mathrm{bp}$ at $\mathrm{CH} 03 \mathrm{a} 09,156 \mathrm{bp}$ and $188 \mathrm{bp}$ at $\mathrm{CH} 01 \mathrm{c} 06,224 \mathrm{bp}$ and $228 \mathrm{bp}$ at $\mathrm{CH} 02 \mathrm{~d} 08$, and $134 \mathrm{bp}$ at $\mathrm{CH} 01 \mathrm{~d} 09$ ) were not inherited by 'Aika No Kaori' (Table 1). An additional two loci (144 bp at CH01g05 and $191 \mathrm{bp}$ at $\mathrm{CH} 02 \mathrm{~g} 04$ ) were also not inherited by 'Aika No Kaori', assuming its maternal parent to be 'Fuji' (Table 1). In contrast, 37 within 38 alleles in 'Aika No Kaori' had been inherited from 'Fuji' and 'Tsugaru' without discrepancy (Table 1), indicating that 'Aika No Kaori' is a hybrid of those two cultivars (Table 2). One allele (228 bp at CH03d07) in 'Aika No Kaori', not inherited from 'Fuji', was detected only in 'Aika No Kaori'. The 228 bp band might be generated from the corresponding $226 \mathrm{bp}$ in 'Fuji' by an error at DNA replication.

'Korin' is a chance seedling of 'Fuji' $x$ unknown paternal parent. However, the $S$ RNase content of 'Korin' $\left(S, S_{\theta}\right)$ was identical to its reported maternal parent 'Fuji' $\left(S_{l} S_{9}\right)$, suggesting that 'Korin' might be a sport of 'Fuji' (Matsumoto et al., 2003b). The fact that all 38 alleles from the 19 SSR loci in 'Korin' completely matched those in 'Fuji' (Table 1) indicated that 'Korin' was the sport of 'Fuji' (Table 2).

'Kotoku' resulted from a hybrid of 'Toko' ('Golden Delicious' was crossed with 'Indo' in 1930, fruited in 1938, named in 1962) with an unknown paternal parent. However, 'Toko' $\left(S_{2} S_{7}\right)$ seemed not to be the maternal parent of 'Kotoku' $\left(S_{1} S_{28}\right)$ based on the $S$-RNase content analysis (Matsumoto et al., 2003b). From its $S$-RNase content and fruit characteristics, 'Kotoku' $\left(S, S_{28}\right)$ may possibly be a hybrid of 'Fuji' $\left(S_{1} S_{9}\right) \times$ 'Orei' $\left(S_{2} S_{28}\right)$. Based on our results, one allele in each locus of 'Fuji' was inherited by 'Kotoku' without discrepancy (Table 1), suggesting that 'Fuji' was used as a maternal parent of 'Kotoku' (Table 2). We also examined whether or not 'Orei' was a paternal parent of 'Kotoku'. Six alleles at three loci in 'Orei' (178 bp and 198 bp at CH01f07a, 103 bp and $111 \mathrm{bp}$ at $\mathrm{CH} 02 \mathrm{~b} 07$, and $252 \mathrm{bp}$ and $270 \mathrm{bp}$ at $\mathrm{CH01d08)} \mathrm{were} \mathrm{not} \mathrm{inherited} \mathrm{by}$ 'Kotoku' (Table 1). Assuming that 'Fuji' is the maternal parent of 'Kotoku', an additional 10 alleles at five loci in 'Orei' $(204$ bp at $\mathrm{CH} 03 \mathrm{e} 03$,
124 bp at $\mathrm{CH} 03 \mathrm{a} 04,179 \mathrm{bp}$ at $\mathrm{CH} 01 \mathrm{f03b}, 222$ bp at $\mathrm{CH} 02 \mathrm{~d} 08$ and 243 bp at $\mathrm{CH} 02 \mathrm{c} 09$ ) were not inherited by 'Kotoku', suggesting that 'Orei' was not the paternal parent of 'Kotoku' (Table 1). Based on the $S$-RNase content of 'Kotoku' $\left(S_{I} S_{28}\right)$ and its maternal parent 'Fuji' $\left(S S_{g}\right)$, the paternal parent of 'Kotoku' must have the $S_{28}$-allele. We chose 'Starking Delicious' $\left(S_{9} S_{28}\right)$, 'Nero 26' ['45 Gou' (' Jonathan' $\times$ 'Golden Delicious') was crossed with 'Richared Delicious' in 1954, selected in 1961] $\left(S_{4} S_{28}\right)$, Empire (introduced into Japan in 1965) $\left(S_{10} S_{28}\right)$ and Aori 3 ('Toko' was crossed with 'Richared Delious' in 1952, selected in 1963 , named in 1970) $\left(S_{2} S_{28}\right)$ as candidates for the paternal parent of 'Kotoku'. However, all of them were excluded for the reasons given below. Six alleles at three loci in 'Nero 26' (96 bp and $116 \mathrm{bp}$ at $\mathrm{CH} 03 \mathrm{a} 04,194 \mathrm{bp}$ and $198 \mathrm{bp}$ at $\mathrm{CH} 01 \mathrm{f07a}$, and $218 \mathrm{bp}$ and $222 \mathrm{bp}$ at $\mathrm{CH02d08),} \mathrm{eight} \mathrm{at} \mathrm{four} \mathrm{loci} \mathrm{in} \mathrm{'Empire'} \mathrm{(96}$ bp and 118 bp at CH03a04, 192 bp and 198 bp at $\mathrm{CH} 01 \mathrm{f07a}, 172 \mathrm{bp}$ at $\mathrm{CH} 01 \mathrm{~d} 09$ and $208 \mathrm{bp}$ at $\mathrm{CH} 05 \mathrm{c} 04$ ), and four at two loci in 'Aori 3' (112 bp and 122 bp at $\mathrm{CH} 02 \mathrm{c} 02 \mathrm{~b}$, and $218 \mathrm{bp}$ and $224 \mathrm{bp}$ at $\mathrm{CH} 02 \mathrm{~d} 08$ ) were not inherited by 'Kotoku' (Table 1). Moreover, assuming that 'Fuji' is the maternal parent of 'Kotoku', 10 alleles at five loci in 'Starking Delicious' (204 bp at $\mathrm{CH} 03 \mathrm{e} 03,96 \mathrm{bp}$ at $\mathrm{CH} 03 \mathrm{a} 04,103 \mathrm{bp}$ at $\mathrm{CH} 02 \mathrm{~b} 07,218$ bp at $\mathrm{CH} 02 \mathrm{~d} 08$, and $172 \mathrm{bp}$ at CH01d09), six at three loci in 'Nero 26' (175 bp at $\mathrm{CH} 05 \mathrm{~g} 08,200$ bp at $\mathrm{CH} 03 \mathrm{e} 03$ and 132 bp at $\mathrm{CH} 01 \mathrm{~d} 09$ ), eight at four loci in 'Empire' (180 bp at $\mathrm{CH} 05 \mathrm{~g} 08,186 \mathrm{bp}$ at $\mathrm{CH} 03 \mathrm{e} 03,152$ bp at $\mathrm{CH} 01 \mathrm{~g} 05$, and 233 bp at $\mathrm{CH} 02 \mathrm{c09}$ ), and 18 at nine loci in 'Aori 3' (175 bp at CH05g08, 204 bp at $\mathrm{CH} 03 \mathrm{e} 03,96$ bp at $\mathrm{CH} 03 \mathrm{a} 04,131$ bp at $\mathrm{CH} 03 \mathrm{a} 09,111$ bp at $\mathrm{CH} 02 \mathrm{~b} 07,132 \mathrm{bp}$ at $\mathrm{CH} 01 \mathrm{~d} 09,208$ bp at $\mathrm{CH} 05 \mathrm{c0} 4,140 \mathrm{bp}$ at $\mathrm{CH} 01 \mathrm{~g} 05$ and 243 bp at $\mathrm{CH} 02 \mathrm{c09}$ ) were not inherited by 'Kotoku' (Table 1). A clone possessing the $S_{28}$-allele that was unregistered during the breeding process might have been used as a paternal parent of 'Kotoku'.

Both 'Tsugaru' and 'Yoko' were produced as hybrids of 'Golden Delicious' with an unknown paternal parent. Either of 'Megumi' ('Ralls Janet' was crossed with 'Jonathan' in 1931, named in 1948, registered in 1950) $\left(S_{2} S_{q}\right)$, 'Fuji' $\left(S_{t} S_{q}\right)$ or 'Jonathan' (introduced into Japan in 1871) $\left(S_{-} S_{g}\right)$ could have been the paternal parent of 'Yoko' $\left(S_{3} S_{9}\right)$ based on their $S$-RNase contents and fruit characteristics. Six alleles at three loci in 'Megumi' (206 bp and 226 bp at $\mathrm{CH} 03 \mathrm{~d} 07,190 \mathrm{bp}$ and 196 bp at $\mathrm{CH} 01 \mathrm{f07a}$, and $250 \mathrm{bp}$ and $254 \mathrm{bp}$ at CH02d08), and 10 at five loci in 'Fuji' (131 bp at $\mathrm{CH} 03 \mathrm{a} 09,226 \mathrm{bp}$ at $\mathrm{CH} 03 \mathrm{~d} 07,158 \mathrm{bp}$ and $160 \mathrm{bp}$ at $\mathrm{CH} 01 \mathrm{c06}, 212 \mathrm{bp}$ at $\mathrm{CH} 02 \mathrm{~d} 08$, and 233 bp and $245 \mathrm{bp}$ at $\mathrm{CH} 02 \mathrm{c09}$ ) were not inherited by 'Yoko' (Table 1). Moreover, four alleles at two loci in 'Megumi' (175 bp at $\mathrm{CH} 05 \mathrm{~g} 08$ and $270 \mathrm{bp}$ at $\mathrm{CH} 01 \mathrm{~d} 08$ ), and eight at four loci in 'Fuji' (175 bp at CH05g08, 94 bp at $\mathrm{CH} 03 \mathrm{a} 04,206$ bp at $\mathrm{CH} 01 \mathrm{f07a}$ and 192 bp at $\mathrm{CH} 02 \mathrm{~g} 04$ ) were not inherited by 'Yoko' assuming the maternal parent to be 'Golden Delicious' (Table 1). In contrast, all 38 alleles in 'Yoko' had been inherited from 'Golden Delicious' and 'Jonathan' without discrepancy 
(Table 1), indicating that 'Yoko' is a hybrid of those two cultivars (Table 2).

'Jonathan' and 'American Summer Pearmain' (discovered in 1817) were thought to be candidates for the paternal parent of 'Tsugaru' from the breeding register. 'Jonathan' $\left(S_{7} S_{9}\right)$, not 'American Summer Pearmain' $\left(S_{1} S_{20}\right)$ seemed to be the paternal parent of 'Tsugaru' $\left(S_{3} S_{7}\right)$ based on the $S$-RNase contents and fruit characteristics of both. All 38 alleles in 'Tsugaru' had been inherited from 'Golden Delicious' and 'Jonathan' without discrepancy (Table 1), confirming that 'Tsugaru' is a hybrid of both those cultivars (Table 2).

\section{Literature Cited}

Bowers, J.E. and C.P. Meredith. 1997. The parentage of a classic wine grape, Cabernet Sauvignon. Nature Genet. 16:84-87.

Bowers, J., J.-M. Boursiquot, P. This, K. Chu, H. Johansson, and C. Meredith. 1999. Historical genetics: The parentage of Chardonnay, Gamay, and other wine grapes of Northeastern France. Science 285:1562-1565.

Broothaerts, W. 2003. New findings in apple Sgenotype analysis resolve previous confusion and request the re-numbering of some S-alleles. Theor. Appl. Genet. 106:703-714.

Franklin-Tong, N. (V.E.) and F.C.H. Franklin. 2003. Gametophytic self-incompatibility inhibits pollen tube growth using different mechanisms.

Table 1. SSR genotypes of 22 apple cultivars

\begin{tabular}{|c|c|c|c|c|c|}
\hline \multirow{2}{*}{$\begin{array}{l}\text { Cultivar } \\
\text { name }\end{array}$} & \multicolumn{5}{|c|}{ SSR genotype (bp) } \\
\hline & $\mathrm{CH} 05 \mathrm{~g} 08$ & $\mathrm{CH} 03 \mathrm{e} 03$ & $\mathrm{CH} 02 \mathrm{c} 02 \mathrm{~b}$ & CH03a04 & CH03a09 \\
\hline Fuji & $175 / 175$ & $186 / 198$ & $112 / 116$ & $94 / 124$ & $131 / 131$ \\
\hline Hida & $175 / 175$ & $186 / 204$ & $112 / 116$ & $94 / 124$ & $131 / 131$ \\
\hline Orin & $175 / 175$ & $200 / 200$ & $112 / 122$ & $124 / 124$ & $135 / 139$ \\
\hline Orei & $175 / 179$ & $186 / 204$ & $112 / 116$ & $124 / 124$ & $135 / 135$ \\
\hline Golden Delicious & $175 / 175$ & $200 / 204$ & $116 / 122$ & $124 / 124$ & $131 / 135$ \\
\hline Ryoka No Kisetsu & $175 / 175$ & $186 / 198$ & $112 / 116$ & $94 / 124$ & $131 / 131$ \\
\hline Starking Delicious & $175 / 179^{z)}$ & $186 / 204^{z)}$ & $112 / 116^{z)}$ & $96 / 124^{z)}$ & $131 / 135^{z)}$ \\
\hline Hokuto & $175 / 175 / 175$ & $186 / 198 / 204$ & $112 / 116 /$ & $94 / 124 /$ & $131 / 135 /$ \\
\hline Mutsu & 175/179/ & $186 / 200 / 204$ & $112 / 116 / 122$ & $120 / 124 /$ & $131 / 135 / 139$ \\
\hline Indo & $175 / 179$ & $186 / 200$ & $112 / 112$ & $120 / 124$ & 131/139 \\
\hline Shin Indo & $175 / 179$ & $186 / 204$ & $112 / 116$ & $120 / 124$ & $131 / 135$ \\
\hline Aika No Kaori & $175 / 175$ & $186 / 198$ & $112 / 112$ & $94 / 124$ & $131 / 131$ \\
\hline Yoko & $175 / 179$ & $198 / 204$ & $112 / 116$ & $116 / 124$ & $135 / 143$ \\
\hline Megumi & $175 / 175$ & $198 / 206$ & $112 / 112$ & $94 / 116$ & $131 / 143$ \\
\hline Tsugaru & $175 / 175$ & $198 / 200$ & $112 / 122$ & $116 / 124$ & $131 / 131$ \\
\hline Jonathan & $175 / 179$ & $198 / 206$ & $112 / 112$ & $100 / 116$ & $131 / 143$ \\
\hline Korin & $175 / 175$ & $186 / 198$ & $112 / 116$ & $94 / 124$ & $131 / 131$ \\
\hline Kotoku & $175 / 179$ & $186 / 206$ & $116 / 116$ & $100 / 124$ & $131 / 135$ \\
\hline Toko & $175 / 175$ & $186 / 204$ & $112 / 122$ & $120 / 124$ & $131 / 139$ \\
\hline Nero 26 & $175 / 175$ & $186 / 200$ & $112 / 116$ & $96 / 116$ & $135 / 143$ \\
\hline Empire & $175 / 180$ & $186 / 186$ & $116 / 116$ & $96 / 118$ & $135 / 139$ \\
\hline \multirow[t]{2}{*}{ Aori 3} & $175 / 175$ & $186 / 204$ & $112 / 122$ & $96 / 124$ & 131/131 \\
\hline & $\mathrm{CH} 03 \mathrm{~d} 07$ & $\mathrm{CH} 03 \mathrm{~d} 12$ & $\mathrm{CH} 01 \mathrm{c} 06$ & $\mathrm{CH} 01 \mathrm{f} 03 \mathrm{~b}$ & $\mathrm{CH} 01 \mathrm{f} 07 \mathrm{a}$ \\
\hline Fuji & $226 / 226$ & $116 / 124$ & $158 / 160$ & $171 / 179$ & $178 / 206$ \\
\hline Hida & $188 / 226$ & $116 / 124$ & $156 / 158$ & $139 / 171$ & $178 / 198$ \\
\hline Orin & $206 / 226$ & $124 / 124$ & $162 / 188$ & $139 / 177$ & $196 / 198$ \\
\hline Orei & $206 / 206$ & $124 / 124$ & $160 / 162$ & $171 / 179$ & $178 / 198$ \\
\hline Golden Delicious & $188 / 206$ & $124 / 124$ & $156 / 162$ & $139 / 171$ & $178 / 198$ \\
\hline Ryoka No Kisetsu & $226 / 226$ & $116 / 124$ & $158 / 160$ & $171 / 179$ & $178 / 206$ \\
\hline Starking Delicious & $206 / 226^{z)}$ & $\left.116 / 124^{y}\right)$ & $160 / 160^{\mathrm{x}}$ & $139 / 179^{z)}$ & $198 / 206^{2}$ \\
\hline Hokuto & $188 / 226 /$ & $116 / 124 /$ & $158 / 160 / 162$ & $171 / 177 / 179$ & $178 / 206 /$ \\
\hline Mutsu & $188 / 206 / 226$ & $116 / 124 /$ & $156 / 162 / 188$ & 139/171/177 & 178/198/ \\
\hline Indo & $218 / 226$ & $116 / 124$ & $160 / 188$ & $177 / 179$ & $178 / 196$ \\
\hline Shin Indo & $206 / 218$ & $116 / 124$ & $162 / 188$ & $139 / 177$ & $178 / 178$ \\
\hline Aika No Kaori & $202 / 228$ & $116 / 124$ & $160 / 162$ & 139/171 & $178 / 178$ \\
\hline Yoko & $188 / 202$ & $124 / 124$ & $156 / 188$ & $139 / 171$ & $178 / 194$ \\
\hline Megumi & $206 / 226$ & $124 / 124$ & $158 / 188$ & $171 / 171$ & $190 / 196$ \\
\hline Tsugaru & $188 / 202$ & $124 / 124$ & $162 / 188$ & 139/171 & 178/194 \\
\hline Jonathan & $202 / 206$ & $124 / 124$ & $188 / 188$ & $171 / 171$ & $194 / 196$ \\
\hline Korin & $226 / 226$ & $116 / 124$ & $158 / 160$ & $171 / 179$ & $178 / 206$ \\
\hline Kotoku & $226 / 226$ & $116 / 124$ & $158 / 160$ & $139 / 171$ & $206 / 206$ \\
\hline Toko & $188 / 218$ & $124 / 124$ & $162 / 188$ & $139 / 177$ & $178 / 178$ \\
\hline Nero 26 & $206 / 226$ & $124 / 124$ & $160 / 162$ & $139 / 171$ & $194 / 198$ \\
\hline Empire & $226 / 226$ & $122 / 124$ & $160 / 162$ & $139 / 171$ & $192 / 198$ \\
\hline Aori 3 & $188 / 226$ & $124 / 124$ & $160 / 162$ & $139 / 139$ & $178 / 206$ \\
\hline
\end{tabular}

Trends in Plant Sci. 8:598-605.

Kimura, T., Y. Sawamura, K. Kotobuki, N. Matsuta, T. Hayashi, Y. Ban, and T. Yamamoto. 2003. Parentage analysis in pear cultivars characterized by SSR markers. J. Jpn. Soc. Hort. Sci. 72:182-189.

Kitahara, K., J. Soejima, H. Komatsu, H. Fukui, and S. Matsumoto. 2000. Complete sequences of the S-genes, Sd- and Sh-RNase cDNA in apple. HortScience 35:712-715.

Kitahara, K. and S. Matsumoto. 2002a. Cloning of the $S_{25}$ cDNA from 'McIntosh' apple and an $S_{25}$-allele identification method. J. Hortic. Sci. Biotechnol. 76:163-166.

Kitahara, K. and S. Matsumoto. 2002b. Sequence of the $S_{10}$ cDNA from 'McIntosh' apple and a PCRdigestion identification method. HortScience 37:187-190.

Liebhard, R., L. Gianfranceschi, B. Koller, C.D. Ryder, R. Tarchini, E. Van De Weg, and C. Gessler. 2002. Development and characterization of 140 new microsatellites in apple (Malus $\times$ domestica Borkh.). Molecular Breeding 10:217-241.

Matsumoto, S., S. Komori, K. Kitahara, S. Imazu, and J. Soejima. 1999a. S-genotypes of 15 apple cultivars and self-compatibility of 'Megumi'. J. Jpn. Soc. Hort. Sci. 68:236-241.

Matsumoto, S., K. Kitahara, S. Komori, and J. Soejima. 1999b. A new $S$-allele in apple ' $S g$ ', and its similarity to the ' $S f$ ' allele from Fuji. HortScience 34:708-710.

Matsumoto, S. and K. Kitahara. 2000. Discovery of a new self-incompatibility allele in apple. HortScience 35:1329-1332.

Matsumoto, S., K. Kitahara, Y. Furusawa, J. Soejima, H. Komatsu, and H. Fukui. 2003a. S-allele genotype of apple cultivars and selections. Acta Hort. 622:389-396.

Matsumoto, S., Y. Furusawa, H. Komatsu, and J. Soejima. 2003b. S-allele genotypes of apple pollenizers, cultivars and linages including those resistant to scab. J. Hortic. Sci. Biotechnol. 78:634-637.

McClure, B.A., V. Haring, P.R. Ebert, M.A. Anderson, R.J. Simpson, F. Sakiyama, and A.E. Clarke. 1989. Style self-incompatibility gene products of Nicotiana alata are ribonucleases. Nature 342:955-957.

Sakurai, K., S.K. Brown, and N.F. Weeden. 1997. Determining the self-incompatibility alleles of Japanese apple cultivars. HortScience 32:1258-1259.

Sefc, K.M., H. Steinkellner, H.W. Wagner, J. Glossl, and F. Regner. 1997. Application of microsatellite markers to parentage studies in grapevine. Vitis 36:179-183.

Soejima, J., K. Abe, N. Kotoda, and H. Kato. 2000. Recent progress of apple breeding at the apple research center in Morioka. Acta Hort. 538:211-214

Testolin, R., T. Marrazzo, G. Cipriani, R. Quarta, I. Verde, M.T. Dettori, M. Pancaldi, and S. Sansavini. 2000. Microsatellite DNA in peach (Prunus persica L. Batsch) and its use in fingerprinting and testing the genetic origin of cultivars. Genome 43:512-520.

Thomas, M., S. Matsumoto, P. Cain, and N.S. Scott. 1993. Repetitive DNA of grapevine: class present and sequences suitable for cultivar identification. Theor. Appl. Genet. 86:173-180.

Yamamoto, T., K. Mochida, T. Imai, T. Haji, H. Yaegaki, M. Yamaguchi, N. Matsuta, I. Ogiwara, and T. Hayashi. 2003. Parentage analysis in Japanese peaches using SSR markers. Breeding Sci. 53:35-40. 
Table 1. SSR genotypes of 22 apple cultivars

\begin{tabular}{|c|c|c|c|c|c|}
\hline \multirow{2}{*}{$\begin{array}{l}\text { Cultivar } \\
\text { name }\end{array}$} & \multicolumn{5}{|c|}{ SSR genotype (bp) } \\
\hline & $\mathrm{CH} 02 \mathrm{~b} 07$ & $\mathrm{CH} 02 \mathrm{~d} 08$ & CH01d09 & $\mathrm{CH} 05 \mathrm{c} 04$ & $\mathrm{CH} 01 \mathrm{~g} 05$ \\
\hline Fuji & $105 / 105$ & $212 / 212$ & $148 / 148$ & $186 / 208$ & $140 / 144$ \\
\hline Hida & $103 / 105$ & $212 / 222$ & $132 / 148$ & $186 / 186$ & $140 / 140$ \\
\hline Orin & $103 / 103$ & $222 / 228$ & $130 / 134$ & $186 / 186$ & $140 / 140$ \\
\hline Orei & $103 / 111$ & $212 / 222$ & $134 / 148$ & $186 / 200$ & $140 / 157$ \\
\hline Golden Delicious & $103 / 111$ & $222 / 224$ & $132 / 134$ & $186 / 200$ & $140 / 146$ \\
\hline Ryoka No Kisetsu & $105 / 105$ & $212 / 212$ & $148 / 148$ & $186 / 208$ & $140 / 144$ \\
\hline Starking Delicious & $103 / 105^{\mathrm{w})}$ & $212 / 218^{z)}$ & $148 / 172^{z)}$ & $200 / 208^{z)}$ & $144 / 157^{z)}$ \\
\hline Hokuto & $103 / 105 /$ & $212 / 212 / 212$ & $130 / 148 /$ & $186 / 200 / 208$ & $140 / 144 / 157$ \\
\hline Mutsu & $103 / 111 /$ & $222 / 224 / 228$ & $130 / 132 / 134$ & $186 / 200 /$ & $140 / 146 /$ \\
\hline Indo & $103 / 111$ & $212 / 228$ & $130 / 148$ & $186 / 186$ & $140 / 157$ \\
\hline Shin Indo & $103 / 111$ & $212 / 222$ & $130 / 134$ & $186 / 186$ & $140 / 157$ \\
\hline Aika No Kaori & $105 / 105$ & $212 / 254$ & $132 / 148$ & $186 / 208$ & $140 / 146$ \\
\hline Yoko & $103 / 105$ & $224 / 228$ & $134 / 134$ & $186 / 186$ & $140 / 144$ \\
\hline Megumi & $105 / 105$ & $250 / 254$ & $148 / 148$ & $186 / 210$ & $140 / 144$ \\
\hline Tsugaru & $103 / 105$ & $224 / 254$ & $132 / 134$ & $186 / 200$ & $144 / 146$ \\
\hline Jonathan & $105 / 126$ & $228 / 254$ & $134 / 134$ & $186 / 186$ & $144 / 144$ \\
\hline Korin & $105 / 105$ & $212 / 212$ & $148 / 148$ & $186 / 208$ & $140 / 144$ \\
\hline Kotoku & $105 / 126$ & $212 / 228$ & $134 / 148$ & $186 / 200$ & $144 / 157$ \\
\hline Toko & $103 / 111$ & $224 / 228$ & $130 / 132$ & $186 / 200$ & $140 / 157$ \\
\hline Nero 26 & $105 / 126$ & $218 / 222$ & $132 / 148$ & $200 / 208$ & $144 / 157$ \\
\hline Empire & $105 / 126$ & $218 / 228$ & $172 / 172$ & $208 / 208$ & $144 / 152$ \\
\hline \multirow[t]{2}{*}{ Aori 3} & $105 / 111$ & $218 / 224$ & $132 / 148$ & $186 / 208$ & $140 / 144$ \\
\hline & $\mathrm{CH} 01 \mathrm{~d} 08$ & $\mathrm{CH} 02 \mathrm{c} 09$ & $\mathrm{CH} 05 \mathrm{a} 04$ & $\mathrm{CH} 02 \mathrm{~g} 04$ & \\
\hline$\overline{\text { Fuji }}$ & $238 / 252$ & $233 / 245$ & $189 / 195$ & $192 / 192$ & \\
\hline Hida & $238 / 248$ & $245 / 257$ & $166 / 195$ & $192 / 192$ & \\
\hline Orin & $248 / 252$ & $243 / 243$ & $165 / 166$ & $192 / 192$ & \\
\hline Orei & $252 / 270$ & $243 / 245$ & $159 / 195$ & $187 / 192$ & \\
\hline Golden Delicious & $248 / 270$ & $243 / 257$ & $166 / 195$ & $187 / 192$ & \\
\hline Ryoka No Kisetsu & $238 / 252$ & $233 / 245$ & $189 / 195$ & $192 / 192$ & \\
\hline Starking Delicious & $238 / 252^{z)}$ & $245 / 255^{z)}$ & $159 / 189^{z)}$ & $192 / 192^{z)}$ & \\
\hline Hokuto & $238 / 252 /$ & $233 / 243 / 245$ & $189 / 195 /$ & 187/192/ & \\
\hline Mutsu & $248 / 252 / 270$ & $243 / 257 /$ & $166 / 195 /$ & $187 / 192 /$ & \\
\hline Indo & $252 / 252$ & $243 / 245$ & $165 / 195$ & $192 / 192$ & \\
\hline Shin Indo & $248 / 252$ & $243 / 245$ & $165 / 195$ & $192 / 192$ & \\
\hline Aika No Kaori & $238 / 252$ & $233 / 249$ & $189 / 189$ & $187 / 192$ & \\
\hline Yoko & $238 / 270$ & $249 / 257$ & $166 / 189$ & $191 / 192$ & \\
\hline Megumi & $270 / 270$ & $249 / 257$ & $169 / 189$ & 191/192 & \\
\hline Tsugaru & $238 / 248$ & $243 / 249$ & $166 / 189$ & $187 / 191$ & \\
\hline Jonathan & $238 / 270$ & $249 / 257$ & $189 / 189$ & $191 / 191$ & \\
\hline Korin & $238 / 252$ & $233 / 245$ & $189 / 195$ & $192 / 192$ & \\
\hline Kotoku & $238 / 238$ & $245 / 255$ & $189 / 195$ & $192 / 192$ & \\
\hline Toko & $248 / 252$ & $243 / 243$ & $166 / 195$ & $187 / 192$ & \\
\hline Nero 26 & $238 / 248$ & $255 / 257$ & $189 / 195$ & $191 / 192$ & \\
\hline Empire & $252 / 252$ & $233 / 245$ & $189 / 189$ & $192 / 192$ & \\
\hline Aori 3 & $238 / 252$ & $243 / 245$ & $159 / 195$ & $187 / 192$ & \\
\hline
\end{tabular}

${ }^{2}$ Determined by Liebhard et al. (2002) and this work.

${ }^{y}$ Liebhard et al. (2002) has reported the SSR genotype as 124/126 bp, but we detected $116 / 124$ bp instead.

'Liebhard et al. (2002) has reported the SSR genotype as $146 / 160 \mathrm{bp}$, but we could not detect a 146bp allele.

${ }^{w}$ Liebhard et al. (2002) has reported the SSR genotype as 180/182 bp, but we detected

$103 / 105$ bp instead.

Table 2. Analyses of eight parent-offspring relationships by SSR loci.

\begin{tabular}{|c|c|c|}
\hline Cultivar & $\begin{array}{l}\text { Reputed } \\
\text { parents }\end{array}$ & $\begin{array}{l}\text { Our } \\
\text { results }\end{array}$ \\
\hline Hida & Fuji $\times$ Orin & Fuji $\times$ Golden Delicious \\
\hline Ryoka No Kisetsu & Starking Delicious $\times$ Fuji or Sport of Fuji & Sport of Fuji \\
\hline Hokuto & Fuji $\times$ Mutsu & $\begin{array}{l}\text { Fuji } \times \text { unknown pollen parent (neither Mutsu, Indo, nor Shin Indo were used } \\
\text { as pollen parents) }\end{array}$ \\
\hline Aika No Kaori & Fuji $\times$ unknown pollen parent & Fuji x Tsugaru \\
\hline Korin & Fuji $\times$ unknown pollen parent & Sport of Fuji \\
\hline Kotoku & Toko $\times$ unknown pollen parent & $\begin{array}{l}\text { Fuji x unknown pollen parent (neither Orei, Starking Delicious, Nero 26, } \\
\text { Empire nor Aori } 3 \text { were used as pollen parents) }\end{array}$ \\
\hline Tsugaru & Golden Delicious $\times$ unknown pollen parent & Golden Delicious $\times$ Jonathan \\
\hline Yoko & Golden Delicious $\times$ unknown pollen parent & Golden Delicious $\times$ Jonathan \\
\hline
\end{tabular}

